\title{
Age-related changes in arterial blood-gas variables in Holstein calves at moderate altitude
}

This article was published in the following Dove Press journal:

Open Access Animal Physiology

15 May 2014

Number of times this article has been viewed

\author{
Joseph M Neary' \\ Franklyn B Garry' \\ Sarah M Raabis ${ }^{2}$ \\ 'Integrated Livestock Management, \\ Department of Clinical Sciences, \\ College of Veterinary Medicine and \\ Biomedical Sciences, Colorado State \\ University, Fort Collins, CO, USA; \\ ${ }^{2}$ Department of Clinical Sciences, \\ University of Wisconsin, Madison, \\ WI, USA
}

\begin{abstract}
The goal of this study was to determine whether peripheral oxygen delivery and efficacy of alveolar-arterial oxygen $\left(\mathrm{A}-\mathrm{a} \mathrm{O}_{2}\right)$ transfer, as estimated from the A-a $\mathrm{O}_{2}$ pressure gradient, are compromised in Holstein calves at moderate altitude. The primary objective was to evaluate age-related changes in arterial blood-gas variables, L-lactate, and hematocrit in healthy calves. The secondary objective was to determine if coughing and nasal discharge, commonly used indicators of respiratory disease, are associated with $\mathrm{A}-\mathrm{a} \mathrm{O}_{2}$ gradient. Arterial blood-gas tensions were evaluated in a cohort of 61 dairy calves on one farm at moderate altitude $(1,601 \mathrm{~m}$ to $1,696 \mathrm{~m}$ ). Sampling was performed on four occasions at approximately 10, 38, 150, and 261 days of age. Hyperventilation, as indicated by hypocapnia, was evident in calves of all ages. Increasing age was associated with a nonlinear increase in arterial oxygen tension $(P<0.001)$ and a nonlinear decrease in $\mathrm{A}-\mathrm{a} \mathrm{O}_{2}$ gradient $(P<0.001)$. The mean $\mathrm{A}-\mathrm{a} \mathrm{O}_{2}$ gradient at 10 and 38 days of age was over $18 \mathrm{mmHg}$, indicating poor efficacy of oxygen transfer. Cough score $(P=0.02)$ but not nasal score $(P=0.32)$ was associated with an in increase in A-a $\mathrm{O}_{2}$ pressure gradient. Mean hematocrit remained low $(<27 \%)$ despite hypoxemia. From 38 days of age, median L-lactate concentration remained over $1.5 \mathrm{mmol} / \mathrm{L}$, indicating substantial anaerobic respiration due to inadequate oxygen delivery. Twenty-five percent of calves were treated for respiratory disease. The maximum age at first treatment was 102 days. In conclusion, there was a nonlinear improvement in A-a $\mathrm{O}_{2}$ transfer efficacy with increasing age, but peripheral oxygen delivery remained compromised. Hyperventilation and impaired A-a $\mathrm{O}_{2}$ transfer due to functional immaturity of the pulmonary system may be risk factors for respiratory disease in dairy calves at moderate altitude.
\end{abstract}

Keywords: calf, dairy, respiratory disease, oxygen

\section{Introduction}

According to the US Geological Survey there are six US states with a mean altitude of over 1,500 m: Colorado, Idaho, Nevada, New Mexico, Utah, and Wyoming. These six states account for $12.6 \%$ (1.16 million) of all milking cows in the US (9.22 million). ${ }^{1}$ This means that over 1 million calves are born and raised at moderate altitude. However, characterization of arterial blood-gas variables in healthy Holstein calves at moderate altitude is lacking. Prior studies have been performed at low altitude and usually focused on one age group. ${ }^{2-5}$

A previous study undertaken in beef calves between 1 and 6 months of age at an altitude of over 2,410 $\mathrm{m}$ was suggestive of inadequate provision of oxygen to peripheral tissues and poor efficacy of alveolar-arterial oxygen $\left(\mathrm{A}-\mathrm{a} \mathrm{O}_{2}\right)$ transfer. ${ }^{6}$ $\mathrm{A}-\mathrm{a} \mathrm{O}_{2}$ transfer efficacy can be evaluated by estimating the $\mathrm{A}-\mathrm{a} \mathrm{O}_{2}$ pressure gradient. 
Impairment of $\mathrm{A}-\mathrm{a} \mathrm{O}_{2}$ transfer is proportional to the $\mathrm{A}-\mathrm{a} \mathrm{O}_{2}$ pressure gradient: the higher the $\mathrm{A}-\mathrm{a} \mathrm{O}_{2}$ pressure gradient the less oxygen is transferred to the blood for a given ventilation rate. The goal of this study was to determine whether peripheral oxygen delivery and efficacy of $\mathrm{A}-\mathrm{a} \mathrm{O}_{2}$ transfer is compromised in dairy calves at moderate altitude, as it appears to be in beef calves at high altitude. ${ }^{6}$ Adequacy of peripheral oxygen delivery was determined by measurement of L-lactate, a product of anaerobic respiration.

Coughing and nasal discharge are clinical signs commonly used by veterinarians and farmers in making a diagnosis of bovine respiratory disease (BRD). ${ }^{7}$ However, there is limited information regarding how these clinical indicators impact the efficacy of alveolar-arterial gas exchange. Therefore, the primary objective of this study was to evaluate age-related changes in arterial blood-gas variables. The secondary objective was to evaluate arterial blood-gas variables in association with nasal discharge and occurrence of coughing.

\section{Materials and methods}

\section{Study herd}

A cohort of Holstein-Friesian calves of a northern Colorado dairy herd with approximately 1,370 milking animals was followed. The study was approved by the Colorado State University Animal Care and Use Committee. Calves were born to both heifers and cows. Only heifer calves were enrolled in this study because bull calves were sold within several days of birth. Four weeks prior to calving, cows and heifers were given an intranasal modified live respiratory disease vaccine offering protection against Bovine herpesvirus 1 (infectious bovine rhinotracheitis), Bovine respiratory syncytial virus (BRSV), and Bovine parainfluenza virus 3 (INFORCE 3; Zoetis Animal Health, Florham Park, NJ, USA) and an Escherichia coli J5 bacterin vaccine (Enviracor J-5; Zoetis Animal Health). At birth and at weaning, when approximately 8 to 9 weeks old, calves were given an intranasal administration of a modified live vaccine offering protection against infectious bovine rhinotracheitis, Bovine parainfluenza virus 3, and BRSV (INFORCE 3; Zoetis Animal Health). Calves were given a live culture Salmonella Dublin vaccine (EnterVene-d; Boehringer Ingelheim Vetmedica Inc., St Joseph, MO, USA) when approximately 2 weeks old. A modified live respiratory disease vaccine (Bovishield Gold FP 5; Zoetis Animal Health) and a bacterin-toxoid vaccine offering protection against seven species of Clostridium (Bar-Vac 7; Boehringer Ingelheim Vetmedica Inc.) were given to calves when approximately 4 to 5 months old.
A calving difficulty score was recorded by the calving attendant; values ranged from 1, no assistance required, to 5, caesarean section delivery required. A calf score of 3 indicated a "hard pull" by the calving attendant.

\section{Calf management}

Calves were fed $2 \mathrm{~L}$ of colostrum on three occasions: at birth and then 2 hours and approximately 12 hours later. Only colostrum with a Brix refractometer value $\geq 22 \%$, equivalent to $50 \mathrm{~g} / \mathrm{L} \mathrm{IgG},{ }^{8}$ was refrigerated for use. Colostrum was used within 2 days of collection.

Calves were housed in individual hutches until 2 to 3 months of age, when they were weaned and moved to small pens of approximately eight calves. Calves were bucket fed 3 L of pasteurized "waste" milk twice per day until 3 weeks old and then 5-6 L once per day until 7 to 8 weeks old. Calves were also bucket fed approximately $2 \mathrm{~kg}$ of mixed grains once per day until 4 months old, when they had ad libitum access to a total mixed ration. The grain mix primarily consisted of rolled oats, barley, corn and a coccidiostat: lasalocid (Bovatec; Zoetis Animal Health).

Serum total protein concentrations of heifer calves, 2 to 7 days old, were routinely evaluated on the dairy using a refractometer. This method is excellent for herd monitoring purposes and provides a reasonably accurate assessment of immunoglobulin transfer status. ${ }^{9}$ Serum total protein concentrations were recorded and evaluated for adequacy of immunoglobulin transfer. At approximately 6 months of age the calves were transported $20 \mathrm{~km}$ north to a heifer raising facility situated at an altitude approximately $100 \mathrm{~m}$ higher than the dairy farm. The fourth test was performed at this facility.

\section{Calf sampling}

Heifer calves born on the dairy from August 3 to August 28, 2012 were sampled on four occasions, targeted at 1 week, 1 month, 5 months, and 9 months of age (Table 1). These ages were chosen in order to evaluate how arterial blood-gas variables change during the transition out of the neonatal period. Samples and measurements taken on each occasion included an arterial blood sample, rectal temperature, and an assessment of nasal discharge and coughing, whether spontaneous or induced by gently pinching the trachea below the larynx. Calves remained on site for the first three test periods. For the first two testing periods the calves were manually restrained in a standing position. During the third and fourth testing periods calves were restrained using headlocks and a chute, respectively. Collection of all measurements, 
Table I The sampling dates, mean calf ages, and number of calves sampled according to test

\begin{tabular}{|c|c|c|c|c|c|}
\hline Test & Altitude, m & $\mathbf{n}^{\mathbf{a}}$ & $n^{b}$ & Dates when sampled & $\begin{array}{l}\text { Mean } \\
\text { age } \pm \mathrm{SD}, \\
\text { days }\end{array}$ \\
\hline I & $\begin{array}{l}\mathrm{I}, 60 \mathrm{I} \\
(5,252 \mathrm{ft})\end{array}$ & 62 & 55 & $\begin{array}{l}\text { August I7-September I, } \\
2012\end{array}$ & $9.8 \pm 4.0$ \\
\hline 2 & $\mathrm{I}, 60 \mathrm{I}$ & 62 & 55 & September $2 I-28,20 I 2$ & $38.4 \pm 6.3$ \\
\hline 3 & $\mathrm{I}, 60 \mathrm{I}$ & $54^{c}$ & $54^{c}$ & January 4-20, 2013 & $150.3 \pm 4.2$ \\
\hline 4 & $\begin{array}{l}1,696 \\
(5,565 \mathrm{ft})\end{array}$ & 55 & 55 & May 3,2013 & $260.5 \pm 8.0$ \\
\hline
\end{tabular}

Notes: ${ }^{2}$ Number of calves sampled; ' number of calves included in the analysis; ' calf during the third test was missing at the time of sampling and subsequently found to be in another pen.

Abbreviation: SD, standard deviation.

including the blood sample, took approximately 5 minutes per calf and no longer than 10 minutes. An arterial blood-draw is a minimally invasive and rapidly performed procedure. Therefore any effect of restraint on the $\mathrm{A}-\mathrm{a} \mathrm{O}_{2}$ gradient was likely to have been minimal.

\section{Blood collection}

Blood was collected from the coccygeal artery using a 22 gauge, $2.54 \mathrm{~cm}\left(1^{\prime \prime}\right)$ hypodermic needle. The bovine coccygeal artery is a suitable source for blood-gas analysis. ${ }^{10,11}$ Syringes were heparinized with approximately $0.25 \mathrm{~mL}$ of sodium heparin $(1,000 \mathrm{IU} / \mathrm{mL})$. The plunger of each syringe was pulled back to the $3 \mathrm{~mL}$ mark, coating the inner chamber surface with heparin. Heparin was then expelled several times so that only the needle hub contained heparin. Approximately $2.5 \mathrm{~mL}$ of blood was collected in a $3 \mathrm{~mL}$ syringe. Dilution of the blood sample $<10 \%$ is sufficient to minimize preanalytic error. ${ }^{12}$ Therefore, given that the syringes contained $<0.25 \mathrm{~mL}$ of heparin following expulsion, preanalytic error due to dilution of the blood sample was minimized. The sample was discarded if during collection the flow of arterial blood was interrupted. Air bubbles within the blood were immediately expelled and the first several drops of blood discarded before immediate analysis, which was performed using a handheld analyser (VetScan i-STAT 1; Abaxis, Union City, CA, USA). Blood-gas tensions were adjusted according to rectal temperature. ${ }^{13}$

\section{Alveolar-arterial oxygen gradient}

The A-a $\mathrm{O}_{2}$ pressure gradient was calculated using the formulas, ${ }^{14}$

$$
\begin{aligned}
& \mathrm{A}-\mathrm{a} \mathrm{O}_{2} \text { pressure gradient }=\mathrm{P}_{\mathrm{A}} \mathrm{O}_{2}-\mathrm{PaO}_{2} \\
& \mathrm{P}_{\mathrm{A}} \mathrm{O}_{2}=\mathrm{FiO}_{2}\left(\mathrm{BP}-\mathrm{pH}_{2} \mathrm{O}\right)-\left(\mathrm{PaCO}_{2} / \mathrm{RQ}\right)
\end{aligned}
$$

where $\mathrm{P}_{\mathrm{A}} \mathrm{O}_{2}$ is estimated alveolar $\mathrm{O}_{2}$ tension $(\mathrm{mmHg}) ; \mathrm{PaO}_{2}$ is measured arterial $\mathrm{O}_{2}$ tension ( $\mathrm{mmHg}$ ); $\mathrm{PaCO}_{2}$ is measured arterial $\mathrm{CO}_{2}$ tension $(\mathrm{mmHg}$ ); RQ is respiratory quotient $(0.9) ;{ }^{15,16} \mathrm{FiO}_{2}$ is fraction of inspired $\mathrm{O}_{2}(0.21)$; $\mathrm{BP}$ is measured barometric pressure $(\mathrm{mmHg})$; and $\mathrm{pH}_{2} \mathrm{O}$ is water vapour pressure at body temperature $\left(52.4 \mathrm{mmHg}\right.$ at $\left.39^{\circ} \mathrm{C}\right)$.

\section{Clinical signs}

Two calf husbandry supervisors monitored calves for signs of ill health every day from birth to the final day of testing: the first supervisor monitored calves from birth to, and inclusive of, the third test; the second supervisor monitored calves from arrival at the offsite heifer raising facility to the fourth test. According to herd protocol, calves are diagnosed and treated for BRD if they have a rectal temperature $\geq 39.7^{\circ} \mathrm{C}$, rapid breathing, abnormal discharge around the nose, harsh lung sounds, and coughing. Veterinarians also assessed calf health on a weekly basis as part of the Colorado State University dairy field service rotation. Signs of ill health along with the date and description of all treatments were recorded in DairyCOMP 305 (Valley Agricultural Software, Tulare, CA, USA).

At the time of each test a "nasal score" and a "cough score" were assigned based on the criterion specified in Table 2. No coughing, whether spontaneous or after gently pinching the trachea below the larynx with forefinger and thumb, was assigned as cough score of 1. A single cough, elicited after gently pinching the trachea, was assigned a score of 2. A cough score of 3 was assigned if multiple coughs were induced by a tracheal pinch. A cough score of 4 was assigned if spontaneous coughing was evident and not induced by tracheal pinch.

\section{Statistical analysis}

Statistical analyses were performed using STATA version 12 (Stata Corporation, College Station, TX, USA). Generalized estimating regression equations, which account for repeated measures, were used with an exchangeable

Table 2 Nasal discharge and cough scoring criteria

\begin{tabular}{lll}
\hline $\begin{array}{l}\text { Nasal or } \\
\text { cough score }\end{array}$ & $\begin{array}{l}\text { Clinical signs of nasal } \\
\text { discharge }\end{array}$ & $\begin{array}{l}\text { Clinical signs of } \\
\text { coughing }\end{array}$ \\
\hline $\mathrm{I}$ & $\begin{array}{l}\text { Clear serous fluid } \\
\text { Unilateral cloudy discharge }\end{array}$ & $\begin{array}{l}\text { No coughing } \\
\text { Induced cough (one } \\
\text { cough only) }\end{array}$ \\
3 & $\begin{array}{l}\text { Bilateral cloudy discharge or } \\
\text { excessive mucous or both }\end{array}$ & $\begin{array}{l}\text { Induced cough ( } \geq \text { two } \\
\text { coughs) }\end{array}$ \\
4 & $\begin{array}{l}\text { Copious bilateral, } \\
\text { mucopurulent discharge }\end{array}$ & $\begin{array}{l}\text { Spontaneous, } \\
\text { noninduced coughing }\end{array}$ \\
\hline
\end{tabular}

Note: A separate score was assigned for nasal discharge and coughing. 
correlation matrix: first, to evaluate the relationship between cough score and nasal score on concurrent $\mathrm{A}-\mathrm{a} \mathrm{O}_{2}$ gradient and arterial $\mathrm{O}_{2}$ tension $\left(\mathrm{PaO}_{2}\right)$ and second, to assess for statistically significant differences in arterial blood-gas variables over time in calves with a cough score of 1 (no cough) at the time of sampling that had not received any treatments for BRD prior to the test period. Eight variables were evaluated for association with age; body temperature was not evaluated (Table 3). In order to achieve a family-wise type one error risk of 0.05 , Bonferroni correction of statistical

Table 3 Mean \pm SD values obtained from calves that had not been treated for respiratory disease prior to the test and had a cough score of I (neither spontaneous nor induced cough)

\begin{tabular}{|c|c|c|c|}
\hline Item & Test & n* & Mean \pm SD \\
\hline \multirow[t]{4}{*}{ Age, days } & 1 & 52 & $10.0 \pm 4.1$ \\
\hline & 2 & 32 & $36.9 \pm 6.0$ \\
\hline & 3 & 40 & $150.2 \pm 4.4$ \\
\hline & 4 & 41 & $259.0 \pm 7.7$ \\
\hline Body temperature, & 1 & 52 & $38.6 \pm 0.3$ \\
\hline \multirow[t]{3}{*}{ Celsius } & 2 & 32 & $39.1 \pm 0.6$ \\
\hline & 3 & 40 & $38.8 \pm 0.3$ \\
\hline & 4 & $4 I$ & $39.0 \pm 0.3$ \\
\hline \multirow[t]{4}{*}{ A-a $\mathrm{O}_{2}, \mathrm{mmHg}$} & 1 & 52 & $22 \pm 8^{a}$ \\
\hline & 2 & 32 & $19 \pm 9^{a}$ \\
\hline & 3 & 40 & $8 \pm 8^{b}$ \\
\hline & 4 & 41 & $7 \pm 8^{b}$ \\
\hline \multirow[t]{4}{*}{$\mathrm{pH}$} & 1 & 52 & $7.45 \pm 0.05^{\mathrm{a}}$ \\
\hline & 2 & 32 & $7.47 \pm 0.05^{b}$ \\
\hline & 3 & 40 & $7.48 \pm 0.03^{b}$ \\
\hline & 4 & 41 & $7.49 \pm 0.04^{c}$ \\
\hline \multirow[t]{4}{*}{$\mathrm{PaCO}_{2}, \mathrm{mmHg}$} & 1 & 52 & $35.9 \pm 5.2$ \\
\hline & 2 & 32 & $37.1 \pm 3.1$ \\
\hline & 3 & 40 & $35.3 \pm 3.3$ \\
\hline & 4 & 41 & $35.3 \pm 2.9$ \\
\hline \multirow[t]{4}{*}{$\mathrm{PaO}_{2}, \mathrm{mmHg}$} & 1 & 52 & $58.9 \pm 9.1^{a}$ \\
\hline & 2 & 32 & $61.2 \pm 8.4^{\mathrm{a}}$ \\
\hline & 3 & 40 & $74.0 \pm 8.9^{b}$ \\
\hline & 4 & 41 & $75.3 \pm 9.1^{b}$ \\
\hline \multirow[t]{4}{*}{ Hematocrit, \% } & 1 & 15 & Not tested \\
\hline & 2 & 31 & $23.4 \pm 4.6^{\mathrm{a}}$ \\
\hline & 3 & 12 & $26.1 \pm 4.3^{b}$ \\
\hline & 4 & 25 & $25.3 \pm 4.6^{b}$ \\
\hline \multirow[t]{4}{*}{$\mathrm{HCO}_{3}, \mathrm{mmol} / \mathrm{L}$} & 1 & 52 & $25.3 \pm 4.6^{\mathrm{a}}$ \\
\hline & 2 & 32 & $27.0 \pm 3.6^{\mathrm{a}}$ \\
\hline & 3 & 40 & $26.5 \pm 3.1^{\mathrm{a}}$ \\
\hline & 4 & 41 & $27.3 \pm 2.8^{\mathrm{b}}$ \\
\hline \multirow[t]{4}{*}{ L-lactate, ${ }^{* *} \mathrm{mmol} / \mathrm{L}$} & 1 & 52 & $(0.37,0.68,0.9 \mathrm{I}, \mathrm{I} .4 \mathrm{I}, 3.22)^{\mathrm{a}}$ \\
\hline & 2 & II & $(0.32,0.75,1.66,2.34,9.43)^{b}$ \\
\hline & 3 & 36 & $(0.35,0.78,1.54,2.06,5.21)^{\mathrm{a}}$ \\
\hline & 4 & 16 & $(1.07,2.15,3.20,4.05,5.98)^{b}$ \\
\hline Oxyhemoglobin & 1 & 52 & $(74.7,88.7,91.5,93.4,97.4)^{2}$ \\
\hline \multirow[t]{3}{*}{ saturation, $* * \%$} & 2 & 32 & $(79.4,90.2,92.2,94.5,96.1)^{2}$ \\
\hline & 3 & 40 & $(89.5,94.8,95.8,97.0,97.8)^{b}$ \\
\hline & 4 & 41 & $(91.0,95.1,95.9,97.1,98.2)^{b}$ \\
\hline
\end{tabular}

Notes: ${ }^{a-c}$ Means for a common variable with different superscripts differ $(P<0.006)$; *Number of calves sampled that met the inclusion criteria;**Minimum, 25th percentile, median, 75th percentile, and maximum values; Data not normally distributed.

Abbreviations: $\mathrm{A}-\mathrm{a} \mathrm{O}_{2}$, alveolar-arterial pressure gradient; $\mathrm{HCO}_{3}$, bicarbonate; $\mathrm{PaCO}_{2}$, arterial $\mathrm{CO}_{2}$ tension; $\mathrm{PaO}_{2}$, arterial $\mathrm{O}_{2}$ tension; $\mathrm{SD}$, standard deviation. values was applied; a probability value $<0.006$ was required for variation in the dependent variable between test periods to be considered statistically significant (Table 3). Serum total protein and the categorical variable, calving difficulty score, were included in all generalized estimating regression analyses to account for potential confounding with the dependent variable. If residual errors were nonnormally distributed, a Skillings-Mack test was used to assess for any statistical difference among test periods. ${ }^{17}$ If statistically significant, Box-Cox regression analysis was performed to determine the appropriate power transformation of the dependent variable. Generalized estimating equations were then used to assess for statistically significant differences between tests. Statistics are reported as mean \pm standard deviation (SD).

\section{Results}

A cohort of 61 calves was followed. Of those, 55 calves were included in the final analysis (Table 1). Six calves were excluded from the dataset. According to herd records two twin calves were sold because of chronic BRD and small size. However, one of the twin calves was diagnosed by auscultation to have a ventricular septal defect. Four calves died during the study: two from presumed BRD, one from a ventricular septal defect, and one from an injury.

\section{Calving}

Of the 55 calves, 43 (78\%) were born with no assistance (calving difficulty score 1$)$, eleven $(20 \%)$ were born with minimal assistance (calving difficulty score 2), and one calf $(2 \%)$ was a "hard pull" (calving difficulty score 3 ). Calves that required minimal assistance were $1.27 \pm 0.50 \mathrm{~kg}$ (mean $\pm \mathrm{SD}$ ) heavier $(P=0.02)$ than calves requiring no assistance during delivery. The single calf requiring extensive assistance was abnormally presented.

\section{Immunoglobulin transfer}

Total serum protein concentrations ranged from $5 \mathrm{~g} / \mathrm{L}$ to $8.9 \mathrm{~g} / \mathrm{L}$ with a mean of $6.5 \pm 0.8 \mathrm{~g} / \mathrm{L}$. Only three calves had total serum proteins $\leq 5.2 \mathrm{~g} / \mathrm{L}$.

\section{Physiological parameters}

Only calves with a cough score of 1 (no cough) at the time of testing that had not been previously treated for BRD were included in the descriptive statistics of blood-gas parameters (Table 3). Calves that had a cough, whether spontaneous or induced by pinching of the trachea, were excluded because coughing significantly influenced $\mathrm{PaO}_{2}$ and $\mathrm{A}-\mathrm{a} \mathrm{O}_{2}$ gradient. The number of calves tested varied among test periods 
because the prevalence of calves with a cough score greater than 1 varied among test periods.

Hyperventilation, as indicated by hypocapnia (arterial $\mathrm{CO}_{2}$ tension $\left.\left[\mathrm{PaCO}_{2}\right]<40 \mathrm{mmHg}\right),{ }^{2-4}$ was evident and did not vary with age $(P=0.13)$. Median $L$-lactate levels remained over $1.5 \mathrm{mmol} / \mathrm{L}$ from test 2 , indicating substantial anaerobic respiration was occurring. Mean hematocrit remained low $(<27 \%)$ throughout the study period.

Age had a nonlinear association with the $\mathrm{A}-\mathrm{a} \mathrm{O}_{2}$ gradient $(P<0.001)$ (Figure 1) and $\mathrm{PaO}_{2}(P<0.001)$ (Figure 2). Pairwise correlation coefficients of A-a $\mathrm{O}_{2}$ gradients ranged from 0.03 to 0.32 and were statistically nonsignificant. Only two of 55 (4\%) calves had an $\mathrm{A}-\mathrm{a} \mathrm{O}_{2}$ gradient $<10 \mathrm{mmHg}$ during the first test, when approximately 1 week old. By the second test, when approximately 5 weeks old, five of $55(9 \%)$ calves had an A-a $\mathrm{O}_{2}$ gradient $<10 \mathrm{mmHg}$. At the third test, when approximately 5 months old, 33 of 54 calves (61\%) had A-a $\mathrm{O}_{2}$ gradients $<10 \mathrm{mmHg}$. At the fourth test, when approximately 9 months old, 35 of 55 (64\%) of calves had A-a $\mathrm{O}_{2}$ gradients $<10 \mathrm{mmHg}$. Ten calves $(19 \%)$ had an estimated A-a $\mathrm{O}_{2}$ gradient $<0 \mathrm{mmHg}$ at the third test and also at the fourth test. This is physiologically impossible and indicates measurement error.

\section{Treatment for respiratory disease}

Prior to the fourth test at approximately 260 days of age, 14 of the 55 calves (25\%) received at least one treatment for BRD (Table 4). Two of the calves treated for BRD were also subsequently treated for bloat. None of the calves with the ten lowest $\mathrm{A}-\mathrm{a} \mathrm{O}_{2}$ gradients $(<16 \mathrm{mmHg})$ at test 1 were treated for BRD. Of these ten calves, five

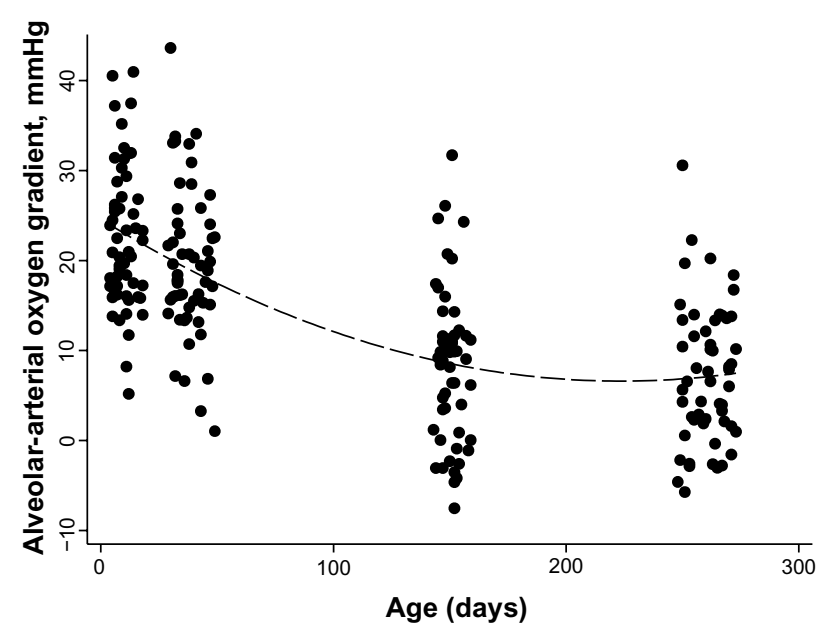

Figure I Alveolar-arterial oxygen pressure gradient in calves by age.

Notes: Dots represent estimated values; Values less than $0 \mathrm{mmHg}$ are physiologically impossible and indicate measurement error; The respiratory quotient used was most likely unsuitable for older calves; The dashed line represents predicted alveolararterial oxygen $(\mathrm{mmHg})=24.6-0.16 *$ age $+0.0004^{*}$ age $^{2}$.

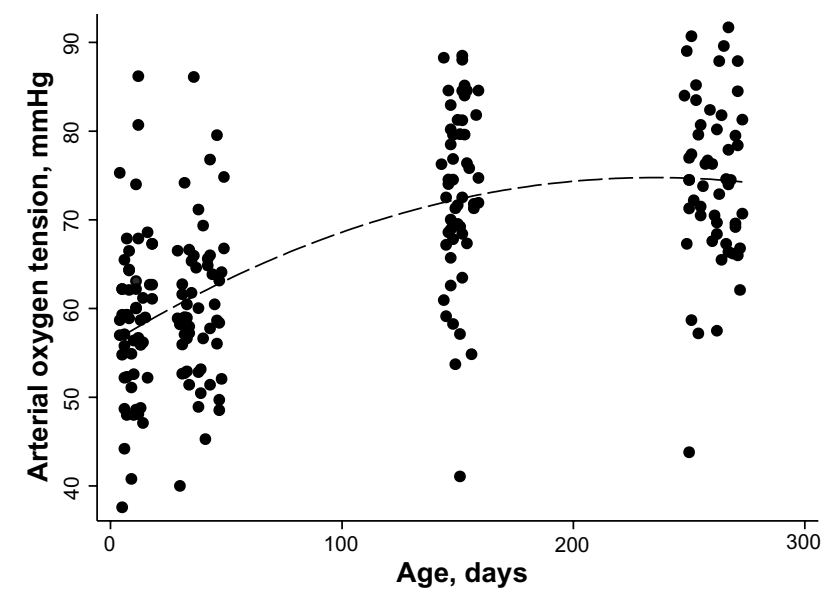

Figure 2 Arterial oxygen tension in calves by age.

Notes: Dots represent measured values; Dashed line represents predicted arterial oxygen tension fitted values $(\mathrm{mmHg})=56.10+0.16 *$ age $-0.0003 *$ age $^{2}$.

(50\%) had an $\mathrm{A}-\mathrm{a} \mathrm{O}_{2}$ gradient $<16 \mathrm{mmHg}$ throughout the study period.

\section{Nasal and cough scores}

The prevalence of calves with a nasal score of 1 (clear, serous fluid) decreased from test 1 ( 55 of 55, 100\%) to test 4 (30 of $55,55 \%$ ). Nasal scores 2 and 3 increased from a prevalence of $11 \%$ (six of 55) and 5\% (three of 55) at the second test to a prevalence of $33 \%$ (eleven of 54) and 13\% (six of 54) at the fourth test, respectively. No calves had a nasal score of 4 (Figure 3).

The prevalence of induced or spontaneous coughing was generally low ( $0 \%$ to $4 \%$ ), except during the second test (33\%). During the first test, $4 \%$ of calves (two of 55) had a cough score of 2 . During the third test, one calf $(2 \%)$ had a cough score of 3 , and one calf had a score of $4(2 \%)$. All 55 calves $(100 \%)$ had a cough score of 1 during the fourth test. Coughing was most prevalent during the second test: four calves $(7 \%)$ had a score of 2, seven calves (13\%) had a score of 3, and seven calves (13\%) had a score of 4 (Figure 4).

Cough score was associated with both $\mathrm{A}-\mathrm{a}_{2}$ pressure gradient $(P=0.02)$ and $\mathrm{PaO}_{2}(P=0.007)$ when controlling

Table 4 The number of calves according to the number of treatments received for respiratory disease and age of first treatment

\begin{tabular}{lll}
\hline $\begin{array}{l}\text { Number of } \\
\text { treatments }\end{array}$ & Number of calves & $\begin{array}{l}\text { Age at first } \\
\text { treatment, days }\end{array}$ \\
\hline 0 & $4 \mathrm{I}(75 \%)$ & - \\
$\mathrm{I}$ & $12(22 \%)$ & $(7,31.5,43.5,91.5,102)^{\mathrm{a}}$ \\
2 & $\mathrm{I}(2 \%)$ & 25 \\
3 & $\mathrm{I}(2 \%)$ & 27 \\
\hline
\end{tabular}

Note: aMinimum, 25th percentile, median, 75 th percentile, and maximum values. 


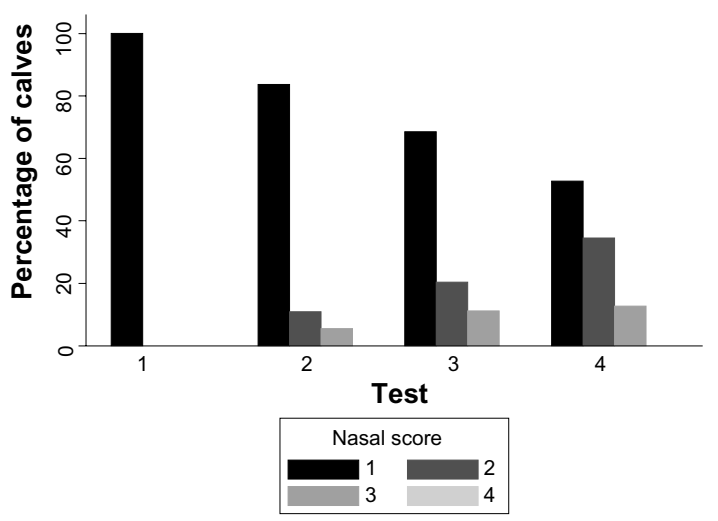

Figure 3 Percentage of calves with nasal scores I to 4 during test periods I to 4 .

for age. Calves with a cough score of 3 had an A-a $\mathrm{O}_{2}$ pressure gradient that was $8.0 \pm 2.8 \mathrm{mmHg}$ higher than calves with a cough score of $1(P=0.005)$. Calves with cough scores of 2 and 4 had A-a $\mathrm{O}_{2}$ pressure gradients that were $2.5 \pm 3.3 \mathrm{mmHg}(P=0.44)$ and $3.9 \pm 2.8 \mathrm{mmHg}(P=0.17)$ higher than calves with a cough score of 1 , respectively, but neither achieved statistical significance. Cough scores of 3 and 4 were associated with a decrease in $\mathrm{PaO}_{2}$ of $8.9 \pm 3.2 \mathrm{mmHg}(P=0.006)$ and $7.5 \pm 3.2 \mathrm{mmHg}(P=0.02)$ relative to a cough score of 1 , respectively. Calves with a cough score of 2 had a $\mathrm{PaO}_{2}$ that was $2.6 \pm 3.8 \mathrm{mmHg}$ lower than calves with a score of 1 , but this was not a statistically significant difference $(P=0.49)$. Nasal score was not associated with $\mathrm{A}-\mathrm{a} \mathrm{O}_{2}(P=0.32)$.

Calves with cough scores $\geq 2$ had rectal temperatures $0.2^{\circ} \mathrm{C} \pm 0.1^{\circ} \mathrm{C}$ higher than calves with a cough score of 1 ( $P=0.03)$. Calves with nasal scores $\geq 2$ did not have higher rectal temperatures than calves with a nasal score of $1(P=0.47)$. Rectal temperature was not correlated with degree of hyperventilation, as indicated by $\mathrm{PaCO}_{2}(P=0.46)$.

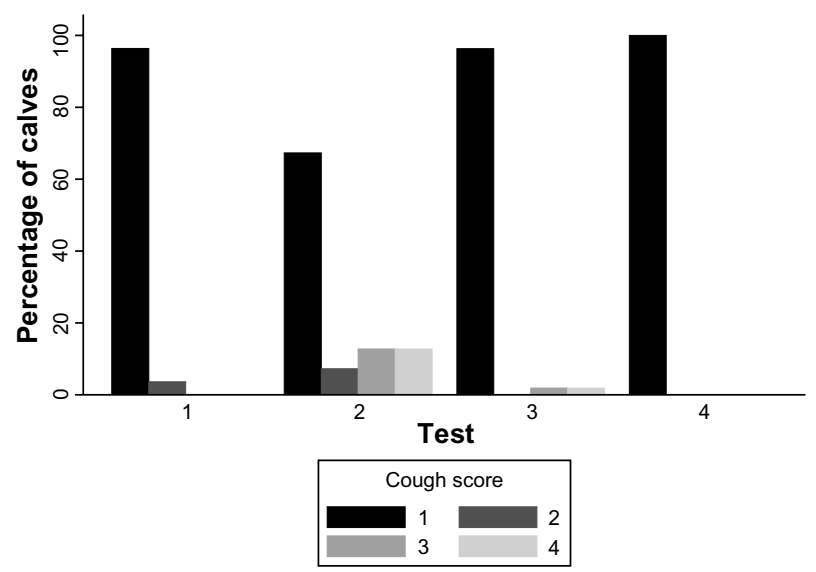

Figure 4 Percentage of calves with cough scores I to 4 during test periods I to 4 .

\section{Discussion}

Previous research conducted on beef calves between 1 and 6 months of age at an altitude of $2,410 \mathrm{~m}$ found that provision of oxygen to peripheral tissues was compromised. ${ }^{6}$ The results of our study suggest that the same may be true in Holstein dairy calves at moderate altitude. From 5 weeks of age, median L-lactate levels remained over $1.5 \mathrm{mmol} / \mathrm{L}$, indicating substantial anaerobic respiration. The concentration of L-lactate in healthy cattle and calves is $<1.5 \mathrm{mmol} / \mathrm{L} .^{18,19}$ Remarkably, despite hypoxemia and substantial anaerobic respiration, mean hematocrit remained low $(<27 \%)$. Lack of a hypoxia-induced increase in hematocrit has also been reported in beef calves. ${ }^{6}$ Why hematocrit fails to increase is unclear.

Hypocapnia, a consequence of hyperventilation, was predominant among all calves in our study, irrespective of age. This may be a consequence of the moderately high altitude at which the calves were tested. The mean $\mathrm{PaCO}_{2}$ in calves at altitudes approximating sea-level has been reported to be over $42 \mathrm{mmHg} .{ }^{2,45}$ Hyperventilation and the associated increased volume of airflow through the bronchial tree results in greater potential for exposure to a greater load of airborne pathogens or stressors, such as dust and dry air, that may sufficiently compromise the respiratory defenses for opportunistic pathogen infection to occur. If ventilatory workload is a risk factor for BRD, as we suggest, the incidence of BRD in dairy calves should be positively associated with altitude. With increasing altitude, the already small pulmonary reserve of calves is further reduced; a greater ventilatory workload is required to deliver the same amount of $\mathrm{O}_{2}$ into the pulmonary circulation. Calves of the Belgian White and Blue "double-muscled" breed are more susceptible to BRD than conventional breeds, not because of a breed-associated immune incompetency, ${ }^{20}$ but rather because of a smaller cardiopulmonary reserve than conventional breeds. ${ }^{15,21}$

At 1 and 5 weeks of age, mean $\mathrm{A}-\mathrm{a} \mathrm{O}_{2}$ pressure gradients were high $\left(>18 \mathrm{mmHg}\right.$ ), indicating that the efficacy of A-a $\mathrm{O}_{2}$ transfer was poor. This may be due to functional immaturity of the cardiopulmonary system. An increase in $\mathrm{PaO}_{2}$ and a reduction in $\mathrm{A}-\mathrm{a} \mathrm{O}_{2}$ pressure gradient in association with increasing age has been previously reported in Friesian calves studied at low altitude. ${ }^{2} \mathrm{An} \mathrm{A}-\mathrm{a} \mathrm{O}_{2}$ pressure gradient $>10 \mathrm{mmHg}$ is an indicator of poor $\mathrm{O}_{2}$ transfer due to ventilation-perfusion mismatching, diffusion impairment, or right-to-left vascular shunt. ${ }^{22}$ At 5 and 9 months of age the majority of calves had A-a $\mathrm{O}_{2}$ pressure gradients that were within normal limits $(<10 \mathrm{mmHg})$. However, ten calves fell below $0 \mathrm{mmHg}$, which is physiologically impossible. This indicates a measurement 
error, which likely occurred because the estimated respiratory quotient (RQ) used in our study was lower than the true RQ. The true mean $\mathrm{A}-\mathrm{a} \mathrm{O}_{2}$ pressure gradient at 5 and 9 months of age was likely higher than the reported mean. An RQ value at rest of 0.9 was used based on the results of previous studies. ${ }^{15,16}$ The RQ is the ratio of $\mathrm{CO}_{2}$ production to $\mathrm{O}_{2}$ consumption and is dependent on diet; a diet high in fat is associated with a significantly lower RQ in cattle than a diet low in fat. ${ }^{23}$ The diet of calves within a given age group or test period was the same. Therefore, for a given test period, RQ was likely similar among calves and measurement error nondifferential. However, diet varied among test periods; consequently, RQ and the degree of measurement error probably differed among age groups. Our study highlights the need for further evaluation of calf pulmonary physiology in field settings. Estimation of $\mathrm{A}-\mathrm{a} \mathrm{O}_{2}$ pressure gradient in future studies should include measurement of the RQ. For the purposes of our study, the trend of a nonlinear improvement in $\mathrm{A}-\mathrm{a} \mathrm{O}_{2}$ transfer efficacy with age is still valid since there was a nonlinear increase in $\mathrm{PaO}_{2}$ with age even though arterial $\mathrm{CO}_{2}$ did not vary with age.

The majority of calves treated for BRD throughout the study period had received a treatment prior to the second test, at age 5 weeks, when the vast majority of calves had an $\mathrm{A}-\mathrm{a} \mathrm{O}_{2}$ gradient $>10 \mathrm{mmHg}$. Among all calves with an $\mathrm{A}-\mathrm{a} \mathrm{O}_{2}$ gradient $>10 \mathrm{mmHg}$, the risk of $\mathrm{BRD}$ may be uniformly high. The greater the gradient, the poorer the efficacy of $\mathrm{A}-\mathrm{a} \mathrm{O}_{2}$ transfer and the greater the ventilatory effort required to achieve, or attempt to achieve, a given $\mathrm{PaO}_{2}$. In support of this conjecture, none of the calves with the ten lowest $\mathrm{A}-\mathrm{a} \mathrm{O}_{2}$ gradients $(<16 \mathrm{mmHg})$ at the first test, when approximately 1 week old, were treated for BRD during the study. Belgian Blue calves with low maximal ventilation (the maximum amount of air that can be inhaled and exhaled in 1 minute) and low vital capacity (the maximum amount of air expelled from the lungs after a maximal inhalation) were found to be at increased risk of BRD. ${ }^{24}$ Further studies evaluating the physiological risk factors for $\mathrm{BRD}$, such as the efficacy of alveolar-arterial gas exchange, are warranted.

The appearance of nasal discharge in calves was not statistically associated with impairment of A-a $\mathrm{O}_{2}$ transfer. Changes in the color, consistency, and quantity of nasal discharge most likely reflect irritation of the nasal mucosa and have little bearing on the efficacy of alveolar-arterial gaseous exchange. However, we cannot say that copious bilateral mucopurulent discharge had no effect on the outcomes of this study as no calf presented with such clinical signs.
The prevalence of coughing was low except during test 2 when calves were approximately 5 weeks old. Two of our findings suggest that the incidence of pathogen challenge in this age group may have been high. Firstly, a small but significant increase in rectal temperature occurred in association with coughing. Secondly, coughing was significantly associated with an increased $\mathrm{A}-\mathrm{a} \mathrm{O}_{2}$ gradient and decreased $\mathrm{PaO}_{2}$, indicating a reduction in the efficacy of $\mathrm{A}-\mathrm{a} \mathrm{O}_{2}$ transfer. One of the many possible causes of the coughing is the viral agent BRSV, which is prevalent among young dairy calves ${ }^{25}$ and has been shown to cause an increase in $\mathrm{A}-\mathrm{a} \mathrm{O}_{2}$ gradient. ${ }^{26,27}$

\section{Conclusion}

This study of Holstein calves at moderate altitude found evidence of substantial hypoxia and poor $\mathrm{A}-\mathrm{a} \mathrm{O}_{2}$ transfer efficacy in calves at 1 and 5 weeks of age. Hyperventilation was evident in all calves irrespective of age. From 5 weeks of age median L-lactate levels remained over $1.5 \mathrm{mmol} / \mathrm{L}$, indicating substantial anaerobic respiration. Cough score but not nasal score was associated with an increase in A-a $\mathrm{O}_{2}$ pressure gradient. Twenty-five percent of calves were treated for BRD. The median and maximum ages of first treatment were 33 and 102 days, respectively, which coincided with the period of high A-a $\mathrm{O}_{2}$ pressure gradients. We speculate that hyperventilation and poor efficacy of $\mathrm{A}-\mathrm{a} \mathrm{O}_{2}$ transfer, which may be due to functional immaturity of the pulmonary system, may be important risk factors for BRD in dairy calves at moderate altitude.

\section{Acknowledgments}

The authors thank Boehringer Ingelheim Vetmedica, Inc. for their financial support of this project through the student bovine research assistantship and La Luna Dairy, Wellington, $\mathrm{CO}$ and The Heifer Authority, LLC for providing access to the calves in the study. Publication funding was generously provided by the Colorado State University Libraries Open Access Research and Scholarship Fund.

\section{Disclosure}

The authors report no conflicts of interest in this work.

\section{References}

1. National Agricultural Statistics Service (NASS), Agricultural Statistics Board, United States Department of Agriculture (USDA). Cattle. Washington, DC: NASS, USDA; 2013. Available from: http://usda01. library.cornell.edu/usda/nass/Catt/2010s/2013/Catt-02-01-2013.pdf. Accessed May 7, 2014.

2. Lekeux P, Hajer R, Breukink HJ. Effect of somatic growth on pulmonary function values in healthy Friesian cattle. Am J Vet Res. 1984;45(10) 2003-2007. 
3. Nagy O, Seidel H, Kovac G, Paulikova I. Acid-base balance and blood gases in calves in relation to age and nutrition. Czech J Anim Sci. 2003;48(2):61-68.

4. Donawick WJ, Baue AE. Blood gases, acid-base balance, and alveolararterial oxygen gradient in calves. Am J Vet Res. 1968;29(3):561-567.

5. Cambier C, Clerbaux T, Detry B, Beerens D, Frans A, Gustin P. Blood oxygen binding in double-muscled calves and dairy calves with conventional muscle conformation. Am J Vet Res. 2000;61(3):299-304.

6. Neary JM, Garry FB, Holt TN, Knight AP, Gould DH, Dargatz DA. Pulmonary arterial pressures, arterial blood-gas tensions, and serum biochemistry of beef calves born and raised at high altitude. Open Access Anim Physiol. 2013;5:1-8.

7. Poulsen KP, McGuirk SM. Respiratory disease of the bovine neonate. Vet Clin North Am Food Anim Pract. 2009;25(1):121-137, vi-vii.

8. Bielmann V, Gillan J, Perkins NR, Skidmore AL, Godden S, Leslie KE. An evaluation of Brix refractometry instruments for measurement of colostrum quality in dairy cattle. J Dairy Sci. 2010;93(8):3713-3721.

9. Weaver DM, Tyler JW, VanMetre DC, Hostetler DE, Barrington GM. Passive transfer of colostral immunoglobulins in calves. J Vet Intern Med. 2000;14(6):569-577.

10. Nagy O, Kováĉ G, Seidel H, Pauliková I. Selection of arteries for blood sampling and evaluation of blood gases and acid-base balance in cattle. Acta Vet Brno. 2002;71(3):289-296.

11. Collie DD. Blood gas and acid-base values in calves, sampled from the brachial and coccygeal arteries. Br Vet J. 1991;147(3):232-237.

12. Hutchison AS, Ralston SH, Dryburgh FJ, Small M, Fogelman I. Too much heparin: possible source of error in blood gas analysis. $\mathrm{Br} \mathrm{Med}$ $J$ (Clin Res Ed). 1983;287(6399):1131-1132.

13. CLSI document C46-A. Blood Gas and Ph Analysis and Related Measurements; Approved Guideline. Wayne, PA: Clinical and Laboratory Standards Institute; 2001. Available from: http://isoforlab. com/phocadownload/csli/C46-A.pdf. Accessed September 20, 2013.

14. Bach JF. Hypoxemia: a quick reference. Vet Clin North Am Small Anim Pract. 2008;38(3):423-426, vii.

15. Gustin P, Dhem AR, Lomba F, Lekeux P. Cardio-pulmonary function values in double-muscled cattle during muscular exercise. Vet Res Commun. 1988;12(4-5):407-416.
16. Kiorpes AL, Bisgard GE, Manohar M. Pulmonary function values in healthy Holstein-Friesian calves. Am J Vet Res. 1978;39(5):773-778.

17. Chatfield M, Mander A. The Skillings-Mack test (Friedman test when there are missing data). Stata J. 2009;9(2):299-305.

18. Figueiredo MD, Nydam DV, Perkins GA, Mitchell HM, Divers TJ. Prognostic value of plasma L-lactate concentration measured cow-side with a portable clinical analyzer in Holstein dairy cattle with abomasal disorders. J Vet Intern Med. 2006;20(6):1463-1470.

19. Constable PD, Streeter RN, Koenig GJ, Perkins NR, Gohar HM, Morin DE. Determinants and utility of the anion gap in predicting hyperlactatemia in cattle. J Vet Intern Med. 1997;11(2):71-79.

20. Michaux C, Brochier B, Roupain J, Pastoret PP, Hanset R, Barta O. Comparison of the immune status of Belgian Blue double muscled and conventional calves by the lymphoblastic transformation test. Ann Med Vet. 1984;128(7):559-564.

21. Gustin P, Bakima M, Art T, Lekeux P, Lomba F, van de Woestijne KP. Pulmonary function values and growth in Belgian white and blue double-muscled cattle. Res Vet Sci. 1988;45(3):405-410.

22. Lekeux P. Pulmonary Function in Healthy, Exercising and Diseased Animals. Ghent, Belgium: University of Ghent; 1993.

23. O'Kelly JC. Influence of dietary fat on some metabolic responses of cattle to fasting. Res Vet Sci. 1985;39(2):254-256.

24. Bureau F, Detilleux J, Dorts T, et al. Spirometric performance in Belgian Blue calves: I. Effects on economic losses due to the bovine respiratory disease complex. J Anim Sci. 2001;79(5):1301-1304.

25. Van Donkersgoed J, Ribble CS, Boyer LG, Townsend HG. Epidemiological study of enzootic pneumonia in dairy calves in Saskatchewan. Can J Vet Res. 1993;57(4):247-254.

26. Lekeux P, Verhoeff J, Hajer R, Breukink HJ. Respiratory syncytial virus pneumonia in Friesian calves: physiological findings. Res Vet Sci. 1985;39(3):324-327.

27. Verhoeff J, Wierda A, van Nieuwstadt AP, Buitelaar JW. Spontaneous bovine respiratory syncytial virus infections in calves: arterial blood gas, $\mathrm{pH}$ and bicarbonate values. Vet Rec. 1985;117(9):202-204.
Open Access Animal Physiology

\section{Publish your work in this journal}

Open Access Animal Physiology is an international, peer-reviewed, open access journal publishing original research, reports, reviews and commentaries on all areas of animal physiology. The manuscript management system is completely online and includes a very

\section{Dovepress}

quick and fair peer-review system. Visit http://www.dovepress.com/ testimonials.php to read real quotes from published authors. 